
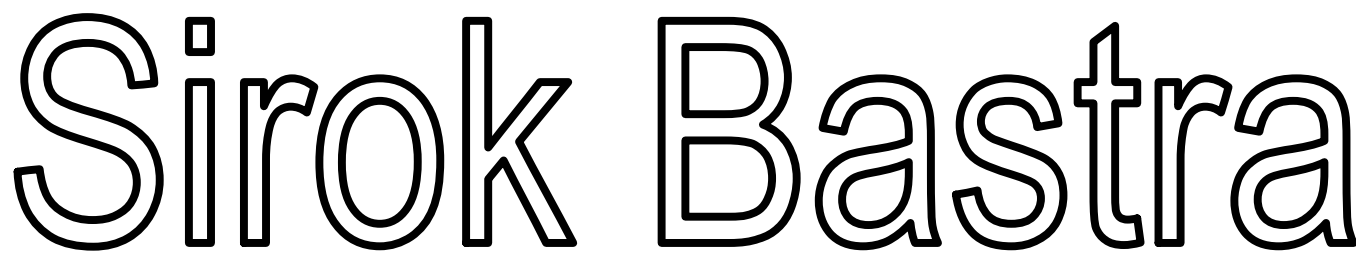

J URNAL ILMIAH KEBAHASAAN DAN KESASTRAAN

\begin{tabular}{|c|c|c|c|c|c|}
\hline $\begin{array}{c}\text { Sirok Bastra } \\
\text { Jurnal Kebahasaan dan } \\
\text { Kesastraan }\end{array}$ & Volume 5 & Nomor 2 & $\begin{array}{c}\text { Hlm. } \\
101-196\end{array}$ & $\begin{array}{c}\text { Pangkalpinang, } \\
\text { Desember } \\
2017\end{array}$ & $\begin{array}{c}\text { ISSN } \\
2354-7200\end{array}$ \\
\hline
\end{tabular}

KANTOR BAHASA KEPULAUAN BANGKA BELITUNG 


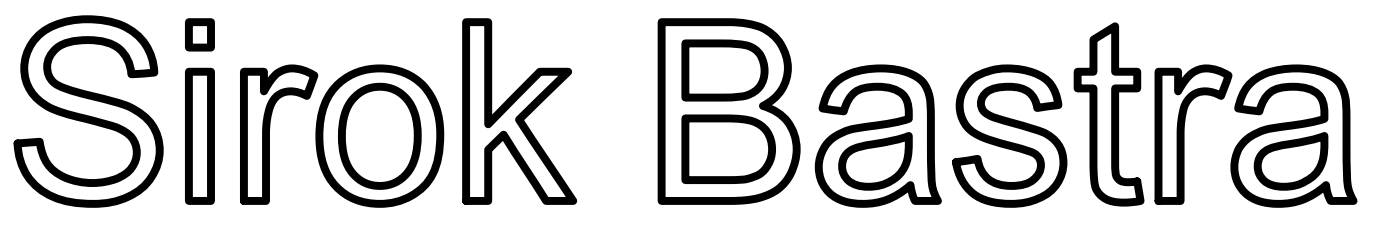

\section{J URNAL ILMIAH KEBAHASAAN DAN KESASTRAAN}

Jurnal ini merupakan wadah informasi kebahasan, kesastraan, dan pengajarannya yang memuat hasil penelitian, studi kepustakaan, dan tulisan ilmiah bidang kebahasan dan kesastraan serta pengajarannya. Sirok Bastra terbit dua kali setahun, yakni Juni dan Desember, serta terbit sejak Juni 2013.

\section{Penanggung Jawab}

Kepala Kantor Bahasa Kepulauan Bangka Belitung

Drs. Hidayatul Astar, M.Hum.

\section{Mitra Bestari}

Prof. Dr. Agus Nuryatin, M.Hum. (Bidang Sastra dan Pengajarannya)

Prof. Amrin Saragih, Ph.D., M.A. (Bidang Bahasa dan Pengajarannya)

Dr. Felicia Nuradi Utorodewo, M.Hum. (Bidang Bahasa dan Pengajarannya)

Dr. Pujiharto, M.Hum. (Bidang Sastra dan Pengajarannya)

\section{Pemimpin Redaksi}

Rahmat Muhidin, S.S.

\section{Penyunting}

Dr. Asyraf Suryadin, M.Pd.

Prima Hariyanto, S.Hum.

Sarman, S.Pd.

\section{Perancang Sampul}

Feri Pristiawan, S.S.

\section{Pengatak}

Dewi Septi Kurniawati, S.Kom.

\section{Kesekretariatan \\ Ria Anggraini, S.E. Juliati, S.E.}

\section{Alamat Redaksi dan Penerbit}

Kantor Bahasa Kepulauan Bangka Belitung

Jalan Letkol Saleh Ode No. 412, Kota Pangkalpinang, Prov. Kepulauan Bangka Belitung Telepon (0717) 438455, Faksimile(0717)9103317, Pos-el: sirokbastra@gmail.com, sirokbastra@kemdikbud.go.id

Pemuatan suatu tulisan dalam jurnal ini tidak berarti redaksi menyetujui isi tulisan tersebut. Isi tulisan menjadi tanggung jawab penulis. Tulisan telah ditinjau dan diulas oleh mitra bestari. Setiap karangan dalam jurnal ini dapat diperbanyak setelah mendapat izin tertulis dari penulis, redaksi, dan penerbit. 


\section{PENGANTAR}

Puji syukur ke hadirat Pemilik dan Pencipta semesta ini yang memiliki kuasa atas diri-Nya sendiri. Dialah Tuhan Yang Maha Esa yang telah memberikan rahmat dan hidayah-Nya sehingga Volume 5 Nomor 2 Jurnal Sirok Bastra Tahun 2017 dapat terbit tepat pada waktunya.

Pada edisi ini dimuat sepuluh tulisan, yakni lima tulisan kebahasaan, empat tulisan kesastraan, dan satu tulisan pengajaran sastra.

Dalam penelitiannya, Hotnida Novita Sary menganalisis iklan komersial Meikarta yang telah membuat perusahaan tersebut berhasil mencatatkan penjualan yang fantastis. Penelitian yang dilakukannya menggunakan pisau bedah analisis wacana kritis Fairclough (1989). Iklan Meikarta membandingkan kesuperioritasan mereka dibandingkan kota metropolitan lain, seperti Jakarta. Meikarta juga menanamkan ideologi bagi masyarakat kota besar bahwa kota metropolitan saat ini sudah tidak aman, kotor, dan macet.

Dalam makalahnya, Hidayatul Astar mengkaji realisasi konsep bahasa Indonesia ke dalam bahasa Rejang. Menurutnya, masyarakat Rejang tidak memiliki konsep (kata atau istilah) yang cukup untuk mewakili pikiran dan perasaan tertentu ketika berkomunikasi, terutama yang terkait dengan konsep kehidupan modern atau yang sesuai dengan perkembangan zaman. Karena itu, bahasa Rejang perlu memungut atau mengambil dari bahasa lain, khususnya dari bahasa Indonesia. Realisasi bentuk konsep yang ditemukan adalah realisasi tanpa perubahan dan realisasi dengan perubahan. Berdasarkan data, realisasi perubahan dalam sebuah konsep dapat satu kali atau lebih. Realisasi perubahan itu berupa penghilangan, penggantian, dan penambahan bunyi vokal atau konsonan tertentu pada posisi tertentu. Terjadinya perubahan realisasi bunyi bahasa Indonsia ke dalam bahasa Rejang disebabkan oleh keinginan penutur bahasa Rejang dan adaptasi terhadap bunyi yang sudah ada.

Dalam kajiannya, Mardi Nugroho membahas pembentukan kata dalam bahasa Talondo di Sulawesi Barat. Hasil analisis data menunjukkan bahwa ada tiga macam cara pembentukan kata dalam bahasa Talondo, yaitu afiksasi, reduplikasi, dan pemajemukan. Pembentukan kata dengan afiksasi terdiri atas pembentukan kata dengan prefiksasi, konfiksasi, infiksasi, dan sufiksasi. Pembentukan kata dengan reduplikasi terdiri atas reduplikasi murni, reduplikasi sebagian, dan reduplikasi yang berkombinasi dengan afiksasi.

Dalam kajiannya, Muhammad Fadely membahas makna dan bentuk pemakaian eufemisme dan disfemisme dalam feature karya Ruslan Ismail Mage yang bermanfaat bagi pengajaran bahasa Indonesia dan pengembangan bahasa di media massa cetak. Hasil analisis menunjukkan bahwa pemakaian eufemisme lebih banyak daripada pemakaian disfemisme. Berdasarkan simpulan tersebut, peneliti menyarankan bahwa dalam menyampaikan suatu informasi kepada khalayak umum hindari tulisan-tulisan yang dapat mengaburkan dan tidak terus terang demi maksud-maksud tertentu.

Dalam kajiannya, Asri Soraya Afsari membahas karakteristik bahasa yang digunakan dalam iklan komersial ponsel yang berada di Kota Bandung. Hasil penelitian menunjukkan bahwa bentuk dan fungsi bahasa yang digunakan dalam iklan ponsel di Kota Bandung berupa penulisan huruf kapital secara keseluruhan dan penulisan huruf kapital pada awal kata. Bahasa iklan ponsel memiliki fungsi informatif dan konatif (persuatif).

Dalam tulisannya, Erwin Wibowo mendeskripsikan makna semiotik budaya Lampung yang ada di dalam antologi Kitab Cerpen Perempuan di Rumah Panggung. Hasil penelitian mengungkapkan ikon, indeks, dan simbol budaya Lampung melalui pendekatan semiotik yang dipakai dalam Kitab Cerpen Perempuan di Rumah Panggung karya Isbedy Stiawan ZS dan memberi deskripsi tentang ikon, indeks, dan simbol tesebut.

Dalam penelitiannya, Prima Hariyanto membahas penokohan dalam Kitab Omong Kosong yang mengambil cerita epos Ramayana. Dalam novel ini, pengarang mengubah pola cerita. Tokoh sentral dalam cerita ini bukan lagi Rama dan Sinta, tetapi Maneka dan Satya. Ceritanya bukan lagi kisah cinta Rama dan Sinta, tetapi kisah perjalanan Maneka dan Satya dalam mencari Kitab Omong Kosong ciptaan Hanoman. Tokoh Rama tidak lagi diceritakan sebagai kesatria yang baik, tetapi sebagai raja yang membawa bencana bagi rakyat di muka bumi.

Dalam kajiannya, Dian Anggraini mengkaji intertekstual lima puisi Indonesia yang berisi tentang sosok wanita yang disebut ibu, yaitu "Ibu Dehulu" (Amir Hamzah), "Ibu” (Chairil Anwar), "Sajak Ibu” (Wiji Thukul), 
"Bunda Air Mata" (Emha Ainun Najib"), dan "Ibu” (K.H. Mustofa Bisri). Hasil telaah itu membuktikan bahwa kelima puisi tersebut merupakan mosaik, kutipan-kutipan, penyerapan, dan perspektif yang beragam terhadap sosok ibu. Setiap penyair mengungkapkan sisi ibu dari pandangan yang berbeda.

Dalam kajiannya, Yuliadi M.R. membahas makna ground dalam cerpen "Uak dan Burung Gagak" dengan pendekatan objektif melalui teori semiotik Pierce. Berdasarkan kajian, terungkap bahwa makna ground dalam cerpen Uak dan Burung Gagak, yaitu ground qualisign berupa warna hitam, sinsign berupa suara koakkoak, dan legisign berupa perilaku mengitari rumah.

Dalam tulisannya, Abdul Azis dan Hajrah membahas dongeng sebagai bahan pembelajaran di sekolah dasar. Data penelitian ini adalah dongeng Cerita Si Jingkiriq, I Kukang, Nenek Pakande, La Dana dan Kerbaunya, dan Puang Tedong. Hasil analisis data dan temuan menunjukkan bahwa rata-rata penilaian responden untuk dongeng sebesar 3,75 (kategori layak dijadikan bahan ajar). Bahan ajar yang dapat digunakan untuk tingkat SD adalah dongeng yang isinya sesuai dengan karakteristik, pengalaman, dan kebutuhan siswa.

Kami mengucapkan terima kasih kepada para penulis yang telah bersedia menerbitkan karya mereka pada edisi ini. Para penulis merupakan peneliti, pakar, dosen, dan mahasiswa dari berbagai perguruan tinggi dan instansi. Terima kasih juga kami sampaikan kepada para mitra bestari kami yang telah memberi ulasan terhadap tulisan-tulisan yang masuk ke redaksi.

Demi memenuhi keberagaman isi dan penulis, Sirok Bastra membuka kesempatan bagi para peneliti dan penulis menyampaikan hasil penelitian dan pemikiran mutakhir dalam bidang kebahasaan, kesastraan, dan pengajarannya. 


\section{UCAPAN TERIMA KASIH UNTUK MITRA BESTARI}

Redaksi Sirok Bastra mengucapkan terima kasih kepada para mitra bestari yang telah meninjau, menimbang, dan mengulas makalah-makalah yang diterbitkan dalam Sirok Bastra Volume 5 Nomor 2, edisi Desember 2017, yakni

Prof. Dr. Agus Nuryatin, M.Hum.

Bidang Sastra dan Pengajarannya

Universitas Negeri Semarang

Semarang, Jawa Tengah

Prof. Amrin Saragih, Ph.D., M.A.

Bidang Bahasa dan Pengajarannya

Universitas Negeri Medan

Medan, Sumatra Utara

Dr. Felicia Nuradi Utorodewo, M.Hum.

Bidang Bahasa dan Pengajarannya

Universitas Indonesia

Depok, Jawa Barat

\section{Dr. Pujiharto, M.Hum.}

Bidang Sastra dan Pengajarannya

Universitas Gadjah Mada

Yogyakarta, Daerah Istimewa Yogyakarta 


\section{DAFTAR ISI}

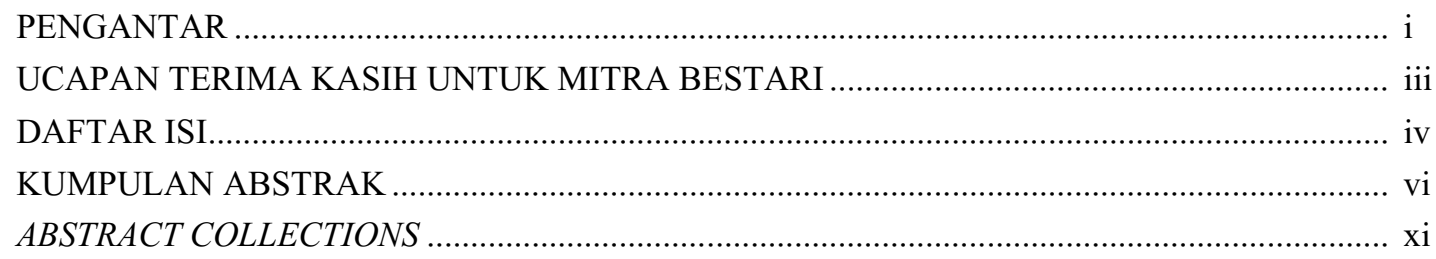

ANALISIS WACANA KRITIS IKLAN KOMERSIAL MEIKARTA

(Critical Discourse Analysis of Meikarta Commercial Advertising)

Hotnida Novita Sary $101-111$

REALISASI KONSEP BAHASA INDONESIA DALAM BAHASA REJANG

(Realization of Indonesian Concept Into Rejang Language)

Hidayatul Astar. $113-121$

PEMBENTUKAN KATA DALAM BAHASA TALONDO

(The Word Formation in Talondo Language)

Mardi Nugroho $123-129$

EUFEMISME DAN DISFEMISME PADA FEATURE-FEATURE KARYA RUSLAN ISMAIL MAGE

(Euphemism and Disphemism in The Features by Ruslan Ismail Mage)

Muhammad Fadely $131-139$

KARAKTERISTIK PENGGUNAAN BAHASA DALAM IKLAN PONSEL DI KOTA BANDUNG

(The Characteristic of Language Usage on Mobile Phone Advertisement in Bandung) Asri Soraya Afsari $141-151$

SIMBOL BUDAYA LAMPUNG DALAM KITAB CERPEN PEREMPUAN DI RUMAH PANGGUNG KARYA ISBEDY STIAWAN Z.S.: KAJIAN SEMIOTIKA

(Lampung Cultural Symbols in Kitab Cerpen Perempuan di Rumah Panggung by Isbedy Stiawan Z.S.: a Semiotic Analysis)

Erwin Wibowo $153-161$

PENOKOHAN DALAM KITAB OMONG KOSONG KARYA SENO GUMIRA AJIDARMA (Characterization in Kitab Omong Kosong by Seno Gumira Ajidarma)

Prima Hariyanto $163-169$

WANITA ISTIMEWA: KAJIAN INTERTEKSTUAL TERHADAP PUISI-PUISI TENTANG IBU

(Special Woman: Intertextual Study of Poems About Mother) 
BURUNG GAGAK SEBUAH TANDA: MAKNA GROUND DALAM CERPEN UAK DAN BURUNG GAGAK

(Brids Crow A Sign: Ground Meaning in Uak and Burung Gagak Short Story)

Yuliadi M.R.

DONGENG SEBAGAI BAHAN PEMBELAJARAN BAHASA INDONESIA DI SEKOLAH

DASAR

(Folktale as Indonesian Language Learning Material in Elementary School)

Abdul Azis dan Hajrah

$191-196$ 
Yuliadi M. R.: Burung Gagak sebuah Tanda: Makna Ground dalam Cerpen Uak dan Burung Gagak

\title{
BURUNG GAGAK SEBUAH TANDA: MAKNA GROUND DALAM CERPEN UAK DAN BURUNG GAGAK
}

Birds Crow A Sign: Ground Meaning in Uak and Burung Gagak Short Story

Yuliadi M.R.

Kantor Bahasa Provinsi Lampung

Jalan Beringin II No. 40, Kompleks Gubernuran, Telukbetung, Bandarlampung

Pos-el: yyuliadi.muh.rahim@gmail.com

(diterima 30 Agustus 2017, disetujui 4 September 2017, revisi terakhir 22 November 2017)

\begin{abstract}
Abstrak
Penelitian ini bertujuan untuk mengungkap makna ground dalam cerpen Uak dan Burung Gagak. Makna ground itu diungkap melalui peristiwa dan dialog tokoh dalam cerpen. Kajian yang digunakan pendekatan objektif dengan teori semiotik Pierce. Teori ini membagi ground pada aspek qualisign, sinsign, dan legisign. Metode yang digunakan dalam penelitian ini adalah metode deskriptif kualitatif dengan teknik pengumpulan data studi pustaka. Berdasarkan kajian, terungkap bahwa makna ground dalam cerpen Uak dan Burung Gagak, yaitu ground qualisign berupa warna hitam, sinsign berupa suara koak-koak, dan legisign berupa perilaku mengitari rumah.
\end{abstract}

Kata kunci: makna ground, cerpen Uak dan Burung Gagak, deskriptif kualitatif

\begin{abstract}
This research is aimed to reveal the ground meaning in Uak dan Burung Gagak short story. The ground meaning would be revealed through the depiction of incident in the story and dialogue. This study used objective approach with semiotic Pierce theory. The theory divide the ground into qualisgn, sinsign, and legisign aspect. The method used in this research is qualitative descriptive method whilst data collection using literary technique. Based on the study, it was revealed that the meaning of ground qualisign aspect is in the form of black, sinsign aspect is the koak-koak sound, and legisign aspect is the behavior flying around the house.
\end{abstract}

Keywords: ground meaning, Uak dan Burung Gagak short story, qualitative descriptive

\section{PENDAHULUAN}

\subsection{Latar Belakang}

Peristiwa yang terjadi dalam kehidupan ini dapat diamati dan dipelajari. Karena terjadinya peristiwa tertentu, dapat dipastikan diawali dengan gejalagejala sebagai bentuk penyebabnya. Jika dapat membaca gejala-gejala itu, sesuatu yang akan terjadi dapat dikendalikan atau diarahkan. Karena itulah, kemampuan membaca sesuatu gejala itu dapat dikatakan sebagai pengetahuan.

Pengetahuan itu bisa didapat dalam karya sastra termasuk cerpen. Cerpen tercipta berkat ide dari alam semesta lalu dituangkan pengarang ke dalam bahasa. Bahasa adalah wadah objektif dari makna dan pengalaman yang besar. Objek itu bukan objek yang mutlak, tetapi objek yang sebagai milik bersama anggota masyarakat terhadap subjektif dalam arti pengertian individual (Teeuw, 1984:227). Untuk itulah, ada pertautan antara gejala alam dan sastra, yang berisikan pengetahuan dan nilai kehidupan.

Gejala alam dalam teks sastra bisa dikatakan merupakan jelma tanda. Kata /gagak/ misalnya, memiliki penanda berupa kata "gagak" dan sebagai petanda burung gagak yang menandai suatu jenis burung yang memiliki arti 'jenis burung yang berbulu hitam dan bersuara kak kaak'. Cerpen Uak dan Burung Gagak berisikan tanda sebagai unsur dalam pokok pembangunnya. Tanda-tanda tersebut bersatu dalam sebuah sistem tanda. Sistem tanda merupakan proyeksi sebuah makna dari realita atau yang ditandakan. Tidak berlebihan jika ingin 
Yuliadi M. R.: Burung Gagak sebuah Tanda: Makna Ground dalam Cerpen Uak dan Burung Gagak

menganalisis cerpen, kita fokus pada tanda-tanda yang membangunnya.

Bahasa sastra dibangun dengan tanda-tanda. Hal menarik yang dikemukakan Pierce terkait dengan tanda dan interpretasi terhadap tanda, adalah hubungannya dengan logika. Adanya konsep segitiga tanda antara ground, denotatum, dan interpretant. Ground adalah dasar atau latar dari tanda, umumnya berbentuk sebuah kata. Denotatum adalah unsur kenyataan tanda. Interpretant adalah interpretasi terhadap kenyataan yang ada dalam tanda.

Aspek tanda tersebut merupakan bentuk pengalaman pengarang dengan alam. Aspek tanda tersebut terlihat dalam penggambaran peristiwa dan dialog tokoh dalam cerpen, berupa pengetahuan tokoh tentang burung gagak, hubungan tokoh dengan kepercayaan, dan penerapan tanda dalam kehidupan. Sastra dengan tandanya mampu menjadi sesuatu yang bermuka dua dengan masing-masing perspektif. Kaitan dengan itu, fokus dari tulisan ini adalah mengungkap makna ground dalam cerpen Uak dan Burung Gagak menurut konsep tanda Pierce.

Tidak hanya alasan didasarkan pada pertimbangan bahwa cerpen Uak dan Burung Gagak karya Mashdar Zainal dimuat di harian Kedaulatan Rakyat, 09 Juli 2017 sebagai objek penelitian, melainkan juga alasan aspek tanda merupakan hal yang utama dalam cerpen Uak dan Burung Gagak sehingga cerpen menjadi khas dan unik serta memiliki makna.

\subsection{Masalah}

Berdasarkan latar belakang, masalah dalam penelitian ini adalah, pertama, "Bagaimanakah aspek ground berupa qualisign, sinsign, and legisign yang terkandung dalam cerpen Uak dan Burung Gagak karya Mashar Zainal? Kedua, makna ground berupa qualisign, sinsign, and legisign yang terkandung dalam cerpen Uak dan Burung Gagak karya Mashar Zainal dengan kajian semiotika? Sebelum menjawab masalah itu ditentukan tujuan penelitian.

\subsection{Tujuan Penelitian}

Penelitian ini bertujuan, pertama, untuk mendeskripsikan aspek ground berupa qualisign, sinsign, and legisign yang terkandung dalam cerpen Uak dan Burung Gagak karya Mashar Zainal. Kedua, untuk mengungkap makna ground berupa qualisign, sinsign, and legisign yang terkandung dalam cerpen Uak dan Burung Gagak karya Mashar Zainal menggunakan kajian semiotik. Kajian semiotik itu akan diungkap melalui gambaran peristiwa dan dialog tokoh dalam teks cerpen.

\subsection{Manfaat}

Penelitian ini dapat digunakan pengembangan ilmu sastra tentang pemahaman terhadap teks khususnya tanda-tanda dalam teks berupa analisis aspek ground dalam cerpen Uak dan Burung Gagak melalui gambaran peristiwa dan dialog tokoh dalam penelitian itu dianalisis dengan pendekatan dari Abrams, yaitu pendekatan objektif yang menitikberatkan pengkajian pada karya sastra itu sendiri. Selain itu, penelitian ini dapat menambah pengetahuan bagi pembaca terutama dalam bidang semiotika.

\subsection{Metode}

Data penelitian ini adalah data primer, yaitu cerpen Uak dan Burung Gagak karya Mashdar Zainal dimuat di harian Kedaulatan Rakyat, 09 Juli 2017. Penelitian ini merupakan kajian deskriptif dengan metode kualitatif. Penelitian kualitatif menurut Sukmadinata (2008:60) adalah suatu penelitian yang dilakukan dengan pendeskripsian fenomena, peristiwa, aktivitas sosial, sikap, kepercayaan, persepsi, pemikiran orang secara individu maupun kelompok. Sejalan dengan pemikiran itu, penelitian kualitatif menurut Moleong (2006: 6) adalah penelitian yang bermaksud untuk memahami fenomena tentang apa yang dialami oleh subjek peneliti, misalnya perilaku, persepsi, motivasi, dan lainnya secara holistik dan dengan cara deskripsi dalam bentuk kata-kata dan bahasa pada suatu konteks khusus yang alamiah dengan memanfaatkan berbagai metode ilmiah. Dapat dikatakan penelitian kualitatif adalah suatu penelitian yang diharapkan 
Yuliadi M. R.: Burung Gagak sebuah Tanda: Makna Ground dalam Cerpen Uak dan Burung Gagak

untuk mendeskripsikan dan menganalisis hal-hal yang ada, dalam kaitan dengan penelitian karya sastra, unsur-unsur pembangunnya.

Informasi didapat dari analisis hasil cerita pada teks cerpen yang selanjutnya sebagai data. Data yang diperoleh kemudian dianalisis dengan dilakukannya interpretasi dan dilanjutkan pendiskripsian. Desain ini dapat dikatakan tiga langkah kerja dalam penelitian, yaitu pengumpulan data, penganalisisan, dan penyajian (Nazir, 2003:55). Dalam usaha mencapai maksud yang telah ditentukan, diperlukan teknik penelitian, yaitu teknik menganalisis data. Langkah-langkah yang diperlukan untuk keperluan adalah sebagai berikut. Pertama, mengadakan studi kepustakaan dilakukan untuk mendapatkan data yang menyangkut aspek makna tanda berupa ground. Kedua, menginventarisasikan data makna tanda dari teks cerpen melalui penggambaran peristiwa dan dialog tokoh. Ketiga, mengindentifikasi data yang diperoleh yang menyangkut aspek ground berupa berupa qualisign, sinsign, dan legisign dalam cerpen. Keempat, merumuskan simpulan penelitian tersebut.

\section{KERANGKA TEORI}

Semiotika berasal dari dari bahasa Yunani, yaitu Semiona yang berarti 'tanda'. Tanda itu didefinisikan sebagai sesuatu yang berada di atas dasar konvensi yang sudah terbangun sebelumnya. Semiotik juga dapat didefinisikan sebagai ilmu yang mempelajari tentang sederet objek-objek, peristiwa dan seluruh kebudayaan sebagai tanda. Zoest mengartikan semiotik sebagai ilmu tanda dan segala sesuatu yang berhubungan dengannya cara berfungsinya, hubungannya dengan kata lain, pengertiannya dan penerimaanya oleh mereka yang menggunakannya (Sobur, 2001: 90). Menurut Peirce, semiotika didasarkan pada logika. Karena logika mempelajari bagaimana orang bernalar sedangkan penalaran dilakukan melalui tanda-tanda. Tanda-tanda ini memungkinkan kita berpikir, berhubungan dengan orang lain dan memberi makna pada apa yang ditampilkan oleh alam semesta.
Tanda dalam kehidupan manusia terdiri dari berbagai macam, antara lain tanda gerak ataupun isyarat, tanda verbal yang dapat berupa ucapan kata, maupun tanda nonverbal yang berupa bahasa tubuh (Sobur, 2006:157). Menurut Danesi (2004: 7) tanda adalah segala sesuatu, warna, isyarat, kedipan mata, objek, rumus matematika, dan lain-lain yang merepresentasikan sesuatu yang lain selain dirinya. Lalu, untuk menentukan tanda setidaknya ada tiga unsur yang harus diperhatikan, yaitu tanda yang dapat ditangkap itu sendiri, yang ditunjuknya, dan tanda baru dalam benak orang yang menginterpretasikannya (Zoest, 1993: 14-15). Dengan demikian, semiotika mempelajari hakikat tentang keberadaan tanda, baik itu dikonstruksikan oleh simbol dan kata-kata yang digunakan dalam konteks sosial (Sobur, 2001:87).

Semiotika dipakai sebagai pendekatan untuk menganalisis sesuatu baik itu berupa teks gambar ataupun simbol di dalam media cetak ataupun elektronik. Dengan asumsi media itu sendiri dikomunikasikan dengan simbol dan kata. Pierce yang merupakan seorang ahli filsafat dan logika menganggap semiotika sebagai sinonim kata logika. Konsep ini sedikit menggambarkan bagaimana semiotik mempelajari cara manusia bernalar melalui tanda-tanda yang memungkinkan mereka berfikir, berhubungan dengan orang lain, dan memberi makna pada apa yang ditampilkan.

Pierce (Pateda, 2001:44, dalam Sobur, 2006:41) dalam teori Ground Triadik mengemukakan tiga hubungan tanda dan klasifikasi tanda. Adapun tiga hubungan tanda yang dimaksudkan adalah ground (dasar), representamen (objek, menghadirkan sesuatu atau mewakili), dan interpretant (penerima, penafsir, atau pengguna tanda). Atas dasar hubungan ini, Peirce mengadakan klasifikasi tanda. Tanda yang dikaitkan dengan ground dibaginya menjadi qualisign, sinsign, dan legisign. Qualisign adalah kualitas yang ada pada tanda, misalnya katakata kasar, keras, lemah, lembut, merdu. Sinsign adalah eksistensi aktual benda atau peristiwa yang ada pada tanda; misalnya kata kabur atau keruh yang ada pada urutan kata air sungai keruh yang 
menandakan bahwa ada hujan di hulu sungai. Legisign adalah norma yang dikandung oleh tanda, misalnya rambu-rambu lalu lintas yang menandakan hal-hal yang boleh atau tidak boleh dilakukan manusia (Christomy dan Yuwono, 2004: 83-84; Sobur, 2006: 40-42).

Untuk itulah, peneliti memosisikan dan memfokuskan penelitian ini pada aspek makna ground dalam cerpen dan menggunakan teori semiotik menurut Pierce. Tanda yang dikaitkan dengan ground dibaginya menjadi qualisign, sinsign, dan legisign. Untuk itu, penelitian aspek ground dalam cerpen Uak dan Burung Gagak berupa qualisign, sinsign, dan legisign dalam cerpen dapat dikaji.

\section{HASIL DAN PEMBAHASAN}

Hasil yang didapat dalam penelitian melalui analisis tanda terhadap cerpen Uak dan Burung Gagak didapat tiga aspek ground, yaitu aspek ground berupa qualisign, yaitu suara burung gagak; aspek ground berupa sinsign, yaitu warna hitam; aspek ground berupa legisign, yaitu berupa mengitari rumah. Makna aspek ground berupa qualisign, sinsign, dan legisign dalam cerpen Uak dan Burung Gagak itu menunjukkan pada sesuatu peristiwa yang menyedihkan akan dialami tokoh. Berikut ini akan dijabarkan lebih rinci dalam pembahasan sebagai berikut.

\subsection{Aspek-Aspek Ground dalam Cerpen Uak dan Burung Gagak}

\subsubsection{Aspek Ground berupa Qualisign: Warna Hitam}

Aspek ground berupa qualisign, yaitu aspek kualitas yang ada pada tanda. Dalam cerpen Uak dan Burung Gagak didapat kualitas yang ada pada tanda, yaitu warna hitam. Aspek tanda ini menunjukkan pada makna celaka atau duka. Warna gagak yang identik dengan sesuatu yang gelap. Hal itu terlihat dalam teks burung gagak yang berwarna sehitam sulang mengitari rumah, seperti yang terlihat dalam kutipan.
Dan seperti yang pernah kusimpulkan, burung sehitam sulang itu kini berputar-putar di atas bubungan rumah kami. Melihatnya aku menjadi sangat cemas. Aku tak mau memikirkan soal kematian, tapi diam-diam aku menebak-nebak siapakah gerangan yang akan disambangi malaikat maut di antara kami. Apakah itu ibu, bapak, kakak-kakakku, atau malah aku sendiri. Tapi rasanya mustahil, semua orang di rumah kami tampak sangat sehat. Jauh dari tanda-tanda kematian. Tapi, sebagaimana yang pernah Uak katakan padaku, kematian itu bisa datang dengan seribu jalan, bukan sekadar sakit.

Kutipan di atas menjelaskan bahwa burung yang berwarna hitam seperti burung sehitam sulang mengitari rumah si aku. Si aku menjadi sangat cemas. Warna hitam dimaknai celaka atau maut. Si aku mencoba menebak siapakah yang akan dicabut dan dipanggil oleh malaikat maut. Suatu hal yang mustahil dirasakan si aku karena di rumahnya tidak ada yang sakit. Namun, kegetiran masih tetap menghinggapi pikiran si aku. Kematian dapat datang kapan dan dimana dengan seribu jalan, tidak selalu dengan sakit.

Warna hitam inipun dapat dianggap sebagai wakil dari peristiwa kesedihan. Karena kesedihan dan duka, seseorang akan menjadi murung dan tidak cerah/ gelap rona. Ketidakcerahan rona akan memberikan sebuah persepsi tekanan dari peristiwa yang dialami atau dirasakan. Tidaklah berlebihan bila warna hitam dikatakan lambang kemalangan atau kedukaan.

Senja hari selepas suara burung hitam itu tak terdengar lagi, aku meringkuk di pangkuan ibu. Rumah cukup sepi. Ayah belum balik kerja, dan kakak-kakakku keluyuran entah ke mana. Aku takut sekali. Maka, kuceritakan pada ibu semua yang telah diceritakan Uak padaku, soal burung hitam itu, soal firasat kematian.

Dalam kutipan di atas terlihat senja selepas suara burung hitam itu berkoak-koak, saat rumah sepi, si aku semakin resah. Suara burung hitam itu membawa firasat kematian. Si aku benar-benar merasakan ketakutan yang dalam. Selain itu, warna hitam itu juga dapat dimaknai malam. Burung gagak itu akan berkoak-koak pada malam hari. Malam yang mempresentasikan hitam dapat dimaknai 
Yuliadi M. R.: Burung Gagak sebuah Tanda: Makna Ground dalam Cerpen Uak dan Burung Gagak

sebagai kegagapan. Karena berjalan di saat malam hari, seseorang akan mengalami kesulitan dan tidak dapat berbuat banyak. Tidak banyak hal yang dapat dilakukan dalam kegelapan. Berjalan pun akan mengalami kesulitan, akan tertatih-tatih dan terbatabata. Begitu pun ketika maut datang, tidak banyak hal yang dapat dilakukan, tidak dapat menghindarinya.

Warna hitam berpengaruh kuat terhadap diri si aku. Dia seperti mengalami traumatis. Warna hitam yang mengisyaratkan kematian telah terpatri dalam pikirannya. Hal itu tidak menguncang diri melainkan juga mengganggu alam sadarnya. Peristiwa itu terlihat dalam kutipan berikut.

Dan sebentar lagi akan melayang ke maja bundar di rumah Uak, lalu Uak menyeruputnya sambil bercerita apa saja kalau aku tak segera enyah dari hadapannya. Asap tipis dari permukaan cangkir berlambaian dihalau angin. Aroma pahit kopi menguar menerobos lubang hidungku. Warna hitam yang berguncang dalam cangkir mengingatkanku pada bulu-bulu gagak yang mengkilap. Aku kembali teringat soal firasat kematian itu.

Kutipan di atas menjelaskan bahwa si aku diminta Ibunya mengantar kopi untuk Uak. Si aku merasa trauma ketika melihat cangkir yang berisi kopi itu berguncang. Pikiran si aku melayang teringat bulu-bulu gagak yang mengkilap. Bulu-bulu gagak yang membawa isyarat kematian.

Dari analisia di atas dapat dikatakan bahwa aspek ground berupa qualis menunjukkan sebuah tanda warna hitam yang kuat mengimplementasikan penanda isyarat kematian. Isyarat kematian itu diwakili oleh warna gelap yang berati murung, sedih, atau kemalangan.

\subsubsection{Aspek Ground Berupa Sinsign: Suara Burung Gagak}

Aspek ground berupa sinsign adalah eksistensi aktual benda atau peristiwa yang ada pada tanda. Dalam cerpen Uak dan Burung Gagak didapat eksistensi aktual benda atau peristiwa yang ada pada tanda. Aspek tanda ini menunjukkan pada makna. Suara gagak yang berbunyi koak, koak, koak dan terdengar mengisi malam sangat jelas. Hal itu terlihat dalam teks. Suara burung gagak yang berkoak koak mengitari rumah, seperti yang terlihat dalam kutipan berikut.

"Seekor burung sehitam sulang beterbangan di atas bubungan rumah kami. Berputar-putar. Berkoak-koak. Uak bilang itu burung gagak. Terdengar jelas dari suaranya yang kaak kaak kaak...."

Kutipan di atas menjelaskan bahwa suara burung gagak yang keras dan lantang pada malam hari. Suara itu dijadikan tanda. Kehadiran suara itu memberikan firasat yang tidak baik akan terjadi. Selain itu, suara itu memberikan suatu tanda karena kehadirannya sangat asing dan menggganggu.

Kehadiran suara itu memberikan reaksi terhadap tokoh lain dalam cerpen. Tokoh si aku memulai alur cerita dalam cerpen. Si aku menanyakan kehadiran suara itu kepada Uaknya. Tokoh Uak menjelaskan kehadiran suara itu seperti dalam kutipan berikut. "Orang-orang terdahulu menandai kabar kematian seseorang dengan burung gagak," ujar Uak suatu kali, sambil menggulung kulit jagung yang berisi rajangan tembakau.

Suara koak-koak pada malam hari, tidak saja membuat cerita berkembang, juga menjadikan polemik dalam diri tokoh. Suara itu menjadikan cerita mengalir dan mendapat reaksi kuat dari tokoh si aku. Dirinya menjadi bertanya-tanya, apakah hubungan suara gagak dengan kematian?

Tokoh Uak menjelaskan bahwa suara itu sudah menjadi tanda akan ada kabar kematian. Pandangan itu telah ada sejak dahulu. Orang-orang dahulu mengartikan suara gagak sebagai tanda akan datang musibah. Musibah yang akan dialami oleh rumah yang dikitari burung gagak itu.

Dari penjelasan itu didapat makna bahwa suara gagak sebagai qualisign yang ditandai dengan suara gagak yang menghancurkan keheningan malam. Suara yang terdengar koak koak dalam keheningan malam. Suara yang menandai sebuah kabar kematian.

Selain itu, si aku telah menjadi fobia dengan suara. Perilaku si aku dalam peristiwa memberikan gambaran bahwa dirinya mulai ketakutan. 
Yuliadi M. R.: Burung Gagak sebuah Tanda: Makna Ground dalam Cerpen Uak dan Burung Gagak

Ketakutan itu selalu dikaitkan dengan suara burung gagak. Sementara kicauan burung prenjak, yang biasanya sebagai petanda akan datang tamu, menjadi perhatian olehnya. Kicauan burung telah menjadi tanda akan terjadi suatu peristiwa. Hal itu tergambar dalam kutipan berikut.

"Tapi kata Uak, burung sering datang sebagai alamat, burung prenjak berkicau di pekarangan rumah sebagai pertanda datangnya tamu. Dulu, waktu Budhe mau datang dari Kalimantan, ada burung prenjak juga yang berkicau di atas pohon petai. Tapi sekarang burung gagak, dan kata Uak...” kataku terpasung, penuh kemurungan.“

Kutipan di atas menjelaskan bahwa si aku menjadi fobia terhadap suara kicauan burung. Pikirannya telah diusik oleh cerita Uak. Suara kicau burung menjadi penanda akan terjadi suatu peristiwa. Suara kicau burung prenjak yang berbunyi di depan rumah sebagai penanda akan datang tamu. Si aku percaya hal itu karena ketika prenjak berkicau di pekarangan rumah, Budhe dari kalimantan datang berkunjung. Hal inilah telah menjadi patokan si aku. Suara burung gagak, yang menurut Uaknya merupakan penanda akan terjadi peristiwa kematian. Tentu, hal ini membuat dirinya merasa terpasung dan penuh kemurungan.

Hal yang dicemaskan si aku memang terjadi. Uak yang hidup sendiri sejak ditinggal istrinya terbujur kaku di kamarnya. Uak meninggal. Si aku semakin yakin ketika sepiker memekik lantang dari bubungan surau. Nama Uak disebut sebagai si mati yang telah dijemput oleh malaikat maut.

“Aku menggoyangkan tubuhnya. Beberapa kali. Dan Uak tetap tak bergerak. Tubuhnya dingin dan sekaku kayu bakar. Aku menghambur menyeru ibu. Lalu silih ibu yang berlarian menyeru para tetangga dengan muka panik. Sekitar sepuluh menit kemudian, aku mendengar suara sepiker memekik lantang dari bubungan surau. Nama Uak disebut di sepiker sebanyak dua kali. Sebagai si mati. Sebagai si mati."

Dari analisis di atas didapat bahwa makna ground berupa sinsign menunjukkan pada sebuah suara burung telah memberikan penanda, yang telah mengonsep dalam diri si aku, akan terjadi suatu peritiwa. Hal ini menjadikan si aku fobia terhadap suara burung. Suara burung gagak telah mengganggu pikirannya. Hal itu juga telah membuat dirinya murung dan terpasung. Sebab suara burung gagak merupakan penanda akan terjadi suatu peritiwa yang menyedihkan, kematian. Kematian akan menimpa salah satu keluarganya.

\subsubsection{Aspek Ground Berupa Legisign: Mengitari Rumah}

Aspek ground berupa Legisign, yaitu norma yang dikandung oleh tanda. Dalam cerpen Uak dan Burung Gagak didapat norma atau aturan yang disepakati bersama dalam masyarakat. Ketika sebuah rumah dikitari oleh burung gagak, salah satu penghuni rumah akan mengalami musibah. Musibah itu berupa kematian. Lebih-lebih lagi burung gagak yang berkoak-koak itu mengitari rumah berkali-kali pada malam hari. Suara koak-koak itu merupakan tanda, tanda yang menunjukkan akan terjadi kematian. Hal itu terlihat dalam kutipan berikut.

"Bisa jadi, dan kalau burung bangkai itu mengitari atap rumah Uakmu ini, bisa dipastikan Uakmu ini yang akan mati," Uak turut menyimpulkan, dengan intonasi sedikit berkelakar. Tapi aku tak sedikitpun menangkap ada yang lucu dari kata-kata Uak.

Kutipan di atas menjelaskan bahwa burung gagak yang mengitari rumah Uak merupakan tanda akan terjadi sesuatu. Uak si aku yang sudah tua merasa usianya telah berakhir. Uak akan mati. Si aku pun menanggapi hal itu adalah keseriusan sebab perkataan Uak tidak ada unsur bercanda atau lucu. Kendati, Uak menyampaikan pendapatnya dengan intonasi sedikit berkelakar.

Namun, apa yang dirisaukan si aku pun terjadi. Hal yang mengganggu pikiran si aku menjadi kenyataan. Sesuatu hal yang diasumsikan Uak tentang gagak yang mengitari rumah, sebagai tanda kematian, benar terjadi. Uak yang tinggal sendirian di sebelah rumahnya meninggal. Hal itu terlihat dalam kutipan berikut.

"Aku mengetuk pintu rumah sebelah dan menerobos begitu saja karena pintu rumah itu tak pernah terkunci. Suara radio sayup-sayup melantunkan iklan anggur kolesom. Aku meletakkan kopi itu di atas meja dan 
Yuliadi M. R.: Burung Gagak sebuah Tanda: Makna Ground dalam Cerpen Uak dan Burung Gagak

menyeru Uak. Tapi Uak tak menyahut. Biasanya begitu aku menyeru soal kopi, Uak segera muncul. Dipan ruang tengah kosong. Aku merunut muasal suara radio yang sudah berganti melantunkan lagu dangdut lawas. Suara itu jelas berasal dari kamar Uak. Benar. Dan di kamar itu, di atas dipan, di sebelah radio yang terus mengoceh, aku mendapati Uak berbaring miring memeluk lutut, berkemul sarung."

Dalam kutipan di atas dijelaskan bahwa si aku mengetuk pintu dan menerobos pintu rumah Uak. Uak memang tidak pernah menguncinya. Si aku biasanya meletakkan kopi di atas meja. Uak akan muncul segera ketika si aku menyeru soal kopi. Akan tetapi, kali ini agak aneh. Tidak seperti biasanya Uak di kamarnya berbaring miring memeluk lutut dan mengemul sarung.

Penjelasan di atas menjadi jawaban atas perilaku gagak mengitari rumah Uak. Uak meninggal. Tanda yang diberikan oleh gagak hitam yang terbang pada malam hari di atas atap rumah sebagai dasar petunjuk akan terjadinya petaka atau musibah. Gagak yang mengitari rumah Uak menunjukkan tanda akan terjadi sesuatu, yaitu salah satu penghuni rumah akan meninggal.

Si aku menanggapi perilaku burung gagak yang mengitari rumah sambil bersuara koak koak. Perilaku burung mengitari rumah dianggapnya sebagai sesuatu yang ganjil. Hal itu menjadi penanda akan terjadi sesuatu atau sebuah "alamat". Perdebatan antara si aku dan Ibu semakin nyata terlihat dalam kutipan berikut. "Hidup dan mati itu urusan Tuhan, bukan urusan burung-burung," ibu menyanggah. Kata-kata yang nyaris sama pernah kudengar dari guru agama di kelasku, bahwa kematian itu memang urusan Tuhan.”

Kutipan di atas menjelaskan bahwa urusan kematian adalah mutlak hak Tuhan. Tidak ada yang mengetahui kepada siapa dan kapan serta dimana diri seseorang akan dipanggil oleh-Nya. Itu adalah rahasia Tuhan. Manusia hanya dapat menyiapkan diri dan menunggu giliran saja.

Si aku tidak berhenti disitu. Karena tanda-tanda kehidupan, Tuhan mengirimnya untuk diketahui oleh hamba-Nya. Si Ibu membela diri dengan mengatakan bahwa bukan berupa burung melainkan uban, sakit, penurunan pendengaran, penglihatan yang buram. Hal itu terlihat dalam kutipan berikut.

"Tapi, bukankah Tuhan kerap mengirim tanda-tanda buat seseorang?" aku berusaha mendebat ibu.

"Dan kiriman itu bukan berupa burung," sahut ibu, cepat, "tapi berupa uban, sakit, pendengaran yang buruk, serta penglihatan yang mulai buram, itu yang ibu tahu," sambung ibu setengah berbisik. Membuatku bungkam, tak hendak membantah kata-katanya lagi.

Dari penjelasan itu didapat bahwa kematian adalah urusan Tuhan. Tanda-tanda yang dikirimkan Tuhan dalam kaitan dengan kematian biasaya berupa uban, sakit, atau penglihatan yang berkurang. Hal ini sebagai penanda bahwa hidup sudah semakin singkat. Akan tetapi, perlu juga dipahami bahwa banyak tanda yang perlu dipelajari. Termasuk pesan dari alam, binatang, atau pun perubahan iklim. Semua itu dapat dijadikan pengetahuan. Semakin banyak mengetahui rahasia alam, semakin tinggi pengetahuan. Hal itu akan menjadikan kita lebih arif dan bijak dalam menyikapi hidup.

Dari analisis di atas didapat bahwa makna ground berupa legisign menunjukkan pada perilaku burung mengitari rumah telah memberikan penanda, bahwa akan terjadi suatu perisitiwa yang menyedihkan. Penanda itu merupakan norma atau aturan yang sadar atau tidak telah disepakati bersama. Perilaku mengitari rumah sebagai bentuk penunjuk atau alamat yang dituju. Salah satu keluarga yang dikitari akan meninggal dunia.

\subsection{Makna Ground dalam Cerpen Uak dan Burung Gagak}

Berdasarkan kajian semiotik terhadap makna ground berupa qualisign, sinsign, and legisign yang terkandung dalam cerpen Uak dan Burung Gagak karya Mashar Zainal mengungkapkan suatu makna bahwa peristiwa yang menyedihkan akan terjadi.

Aspek ground berupa qualis menunjukkan sebuah tanda warna hitam. Warna hitam ini memberikan makna yang kuat sebagai mengimplementasikan penanda isyarat kematian. Isyarat kematian itu diwakili oleh warna gelap yang 
Yuliadi M. R.: Burung Gagak sebuah Tanda: Makna Ground dalam Cerpen Uak dan Burung Gagak

berati murung, sedih, atau kemalangan. Kemalangan merupakan muara dari bentuk kesedihan.

Lalu, makna ground berupa sinsign menunjukkan pada sebuah suara burung telah memberikan penanda. Suara koak-koak yang terjadi dalam masyarakat yang telah mengonsep dalam kultur si aku. Hal itu merupakan sebuah tanda akan terjadi suatu peritiwa. Suara itu menjadikan si aku fobia terhadap suara burung. Suara burung gagak telah mengganggu pikirannya. Sehingga peritiwa itu membuat murung dan terpasung, si aku terbawa oleh pikirannya sendiri. Tidak hanya suara burung gagak yang merupakan penanda akan terjadi suatu peritiwa yang menyedihkan, juga hal itu telah menjadi alamat malapetaka akan menimpa. Tidak hanya diri dan keluarganya bahkan masyarakat di sekitarnya.

Makna ground berupa legisign menunjukkan pada perilaku burung mengitari rumah telah memberikan penanda. Mengitari merupakan suatu kegiatan memberikan gambar atau memetakan tempat sesuatu akan terjadi. Perilaku burung mengitari telah memberikan makna bahwa di tempat peristiwa dikitari akan terjadi hal yang menyedihkan. Penanda itu merupakan norma atau aturan yang sadar atau tidak telah disepakati bersama. Burung mengitari rumah merupakan suatu penunjuk atau alamat akan terjadi sesuatu.

Dari kajian di atas dapat dikatakan bahwa ground qualisign berupa warna hitam, sinsign berupa suara koak-koak, dan legisign berupa perilaku mengitari rumah dalam cerpen Uak dan Burung Hantu memberikan makna secara kuat terhadap tanda akan terjadi sesuatu peristiwa yang menyedihkan. Peristiwa yang akan dialami oleh sesorang berupa kehilangan keluarga atau akan dilanda mala petaka.

\section{PENUTUP}

\subsection{Simpulan}

Dalam cerpen Uak dan Burung Gagak terdapat tiga aspek ground, yaitu aspek ground qualisign berupa warna hitam, sinsign berupa suara koak-koak, dan legisign berupa perilaku mengitari rumah. Ketiga aspek itu berisi tentang gejala alam yang berisi tanda-tanda. Tanda-tanda itu dapat dijadikan pengetahuan, yang terlihat dalam peristiwa yang dialami tokoh dalam cerpen.

Makna tanda dimensi ground dalam cerpen Uak dan Burung Gagak meliputi ground qualisign berupa warna hitam, sinsign berupa suara koakkoak, dan legisign berupa perilaku mengitari rumah merupakan representasi penanda yang dapat diambil sebagai pengetahuan yang berguna untuk menjalani hidup dan menyikapi hidup. Juga tanda yang dapat memberikan pengetahuan dan pemahaman terhadap gejala alam. Bila pengetahuan dan pemahaman terhadap gejala alam, persoalan-persoalan hidup dapat disikapi dan dijalani dengan arif.

\subsection{Saran}

Penelitian terhadap cerpen Uak dan Burung Gagak pun dapat diteliti dari segi struktur dengan pendekatan struktural karena memiliki kekhasan. Selain itu, cerpen Uak dan Burung Gagak ini dapat dilihat nilai-nilai sosial budayanya sehingga pendekatan sosiologi sastra pun dapat dilakukan.

\section{DAFTAR PUSTAKA}

Christomy, Tommy dan Untung Yuwono (ed). 2004. Semiotika Budaya. Depok: Pusat Penelitian Kemasyarakatan dan Budaya Direktorat Riset dan Pengabdian Masyarakat Universitas Indonesia.

Danesi, Marcel. 2004. Pesan, Tanda, dan Makna: Buku Teks Besar Mengenai Semiotika Dan Teori Komunikasi. Yogyakarta: Jalasutra.

Moleong, L.J. 2005. Metode Penelitian Kualitatif. Bandung: Remaja Karya. 
Yuliadi M. R.: Burung Gagak sebuah Tanda: Makna Ground dalam Cerpen Uak dan Burung Gagak

Nazir, Moh. 2003. Metode Penelitian. Jakarta: Ghalia Indonesia.

Pateda, Mansoer. 2001. Semantik Leksikal. Jakarta: PT Rineka Cipta.

Sukmadinata, Nana Syaodih. 2008. Metode Penelitian Pendidikan. Bandung: PT. Remaja Rosdakarya.

Sobur, Alex. 2001. Analisis Teks Media (Suatu Pengantar Untuk Analisis Wacana, Analisis Semiotik dan Analisis Framing). Bandung: PT. Rosdakarya. 2006. Semiotika Komunikasi. Bandung: Remaja Rosdakarya.

Teeuw, A. 1994. Sastra dan Ilmu Sastra. Jakarta: Gramedia.

Wellek, Rene dan Austin Warren. 1989. Teori Kesusasteraan. Jakarta: PT Gramedia.

Zainal, Mashdar. "Cerpen Uak dan Burung Gagak" dalam Harian Kedaulatan Rakyat. Minggu, 09 Juli 2017.

Zoest, Aart Van. 1993. Semiotika Tentang Tanda, Cara Kerjanya dan Apa Yang Kita Lakukan Dengannya. Jakarta: Yayasan Sumber Agung. 
Yuliadi M. R.: Burung Gagak sebuah Tanda: Makna Ground dalam Cerpen Uak dan Burung Gagak 